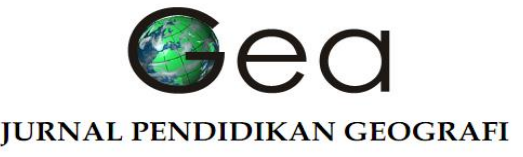

\title{
PEMANFAATAN FENOMENA PERUBAHAN RUANG SIMPANG AMD BATOH DALAM PROSES PEMBELAJARAN GEOGRAFI DI SMA NEGERI 5 BANDA ACEH \\ (Kasus Penggunaan Metode Insiden dan Media Gambar/ Foto dan Ilustrasi pada kelas XI).
}

\author{
${ }^{1}$ Deki Adista \\ ${ }^{2}$ Dede Rohmat \\ ${ }^{3}$ Darsiharjo \\ 1,2,3 Program Studi Magister Pendidikan Geografi \\ Universitas Pendidikan Indonesia
}

\begin{abstract}
ABSTRAK
Pendidik geografi Kota Banda Aceh beranggapan bahwa media pembelajaran selalu berkaitan dengan peralatan elektronik, sebagai pendidik terhadap media dan sumber belajar dilingkungan sekitar untuk mendukung proses pembelajaran geografi seperti fenomena-fenomena yang bersifat kontekstual pada daerah lokal untuk pemahaman konsep peserta didik terkait perubahan ruang Simpang AMD Batoh. Tujuan penelitian menganalisis pemahaman konsep perubahan ruang peserta didik sebelum dan sesudah serta keunggulan dan kelemahan pembelajaran metode insiden dengan media gambar/ foto dan ilustrasi dalam proses pembelajaran geografi. Metode penelitian Quasi Eksperiment. Populasi seluruh peserta didik kelas XI IS SMA Negeri 5 Banda Aceh sebanyak 98 peserta didik, sampel sebanyak 49 peserta didik. Teknik pengumpulan data soal test prestasi, lembar kerja siswa dan lembar observasi dan angket. Teknik analisis data statistik korelasi dan rumus $N$-Gain. Tidak terdapat perbedaan signifikan antara hasil pre-test dan post-test pemahaman konsep perubahan ruang serta antara kelas metode insiden dan kelas media gambar/ foto dan ilustrasi dalam proses pembelajaran geografi. Kedua sampel homogen pada taraf kesalahan $\alpha=0,05$, populasi berdistribusi normal pada taraf kesalahan $\alpha=0,05$, pengujian hipotesis diterima pada taraf kesalahan $\alpha=0,05$. Rekomendasi penelitian diharapkan kepada guru mata pelajaran geografi agar lebih mengedepankan fenomena-fenomena bersifat konten lokal untuk pemahaman konsep perubahan ruang peserta didik dalam proses pembelajaran geografi.
\end{abstract}

\section{PENDAHULUAN}

Perkembangan studi kajian ilmu geografi harus diketahui secara bersama agar para pengembang ilmu pendidikan geografi terutama guru atau pendidik dalam bidang studi geografi baik di kalangan lembaga pendidikan maupun masyarakat, dimana mempelajari salah satu bidang kajian mengenai perubahan-perubahan fenomena-fenomena dan gejala-gejala yang terjadi di ruang permukaan bumi. 
Studi geografi dalam pembahasan dan penganalisisan mengenai suatu objek kajian fenomena dan gejala dalam ruang yang dititik beratkan pada aspek pemanfaatan atau pendayagunaan ruang tidak terlepas dari pertanyaan what, where, when, why dan how, sehingga tidak keluar daripada hakikat dari gejala dan proses mengenai objek kajian terkait pemahaman konsep keruangan geografi dengan mengandalkan analisa keruangan sebagai suatu pendekatan yang khas dalam kajian ilmu geografi. Analisa pemanfaatan perubahan ruang yang digunakan adalah penyebaran lokasi ruang untuk dilakukan perubahan, dimana penyebaran disini tidak hanya dilihat dari aspek perekonomian semata, tetapi dilihat dari segala aspek yang berada di dalam ruang permukaan bumi sebagai pendukung terpenuhinya kebutuhan dasar makhluk hidup, baik dari sosial-ekonomi, sosial-budaya, sosial-politik dan pelestarian lingkungan serta tersedianya ruang untuk dimanfaatkan dan dilakukan perubahan, sebagaimana yang terjadi pada pemanfaatan fenomena perubahan ruang Simpang AMD Batoh Kota Banda Aceh.

Kota Banda Aceh dan sekitarnya adalah satu daerah yang terkena dampak bencana gempa bumi dan tsunami pada 26 Desember 2004. Seiring dengan berjalannya waktu, baik dari pihak nasional maupun internasional, sehingga Kota Banda Aceh di deklarasikan sebagai bencana tingkat internasional dikarenakan banyak menelan korban baik dari segi manusia maupun darisegi infrastruktur, maka dari itu semua relawan memberikan berbagai bantuan, baik dari segi sembako, barak pengungsian sementara dan program-program mengenai Rencana Tata Ruang Wilayah Kota Banda Aceh dan sekitarnya. Walikota Banda Aceh (2009: 43), mengemukakan bahwa:

Gempa bumi dan gelombang tsunami yang melanda kota Banda Aceh pada tanggal 26 Desember 2004 telah mengakibatkan perubahan fungsi ruang dan perkembangan kota, dimana dalam perkembangannya, kota sebagai organisme mempunyai seperangkat elemen-elemen yang membentuk lingkungan kehidupan yang mencirikan sifat-sifat perkotaan. Dalam proses perkembangannya, elemen-elemen kegiatan kota mempunyai kaitan satu sama lain sebagai akibat interaksi yang terjadi dalam aktivitas penduduk sehari-hari.

Perubahan fungsi ruang dan perkembangan Kota Banda Aceh diakibatkan oleh terjadi gempa bumi dan tsunami tanggal 26 Desember 2004, dimana dalam sebuah perkotaan terdapat organisme-organisme atau sekumpulan makhluk hidup baik itu manusia, binatang dan tumbuhan yang dalam interaksi dalam ruang tidak dapat dipisahkan satu sama lain dalam satu sistem ruang permukaan bumi yang mencirikan sifat-sifat perkotaan dari makhluk hidup yang menempati ruang permukaan bumi.

Berdasarkan hasil observasi awal yang dilakukan adalah kurang tanggapnya pihak sekolah terutama dari guru bidang studi geografi dan peserta didik dalam menanggapi 
fenomena-fenomena dan gejala-gejala yang terjadi secara kontekstual pada daerah lokal, sehingga membuat mata pelajaran geografi menjadi tidak menarik dan membosankan serta menjadikan peserta didik tidak peka terhadap fenomena-fenomena dan gejala-gejala yang terjadi disekitar dalam ruang permukaan bumi, hal ini salah satunya disebabkan oleh persepsi guru yang sudah membudaya khususnya dalam proses pembelajaran geografi yang hanya mengandalkan media gambar/ foto dan ilustrasi dan bahkan ada beberapa guru yang masih melakukan proses pembelajaran dengan metode ceramah.

Pemberian pengalaman langsung dengan menggunakan metode observasi langsung yang dilakukan oleh peserta didik dan memperlihatkan gambar/ foto dan ilustrasi sangatlah diperlukan dalam proses pembelajaran geografi agar peserta didik tidak menghayal di saat proses belajar mengajar berlangsung di dalam kelas dalam hal pemahaman konsep dikarenakan dengan menggunakan media gambar/ foto dan ilustrasi atau metode observasi langsung ke lapangan akan membuat mata pelajaran geografi secara tidak langsung menjadi menarik dan dapat memberikan pemahaman dari yang abstrak menjadi konkrit mengenai objek fenomenafenomena di permukaan bumi yang kontekstual dan bersifat daerah lokal sebagaimana yang terjadi pemanfaatan fenomena perubahan ruang Simpang AMD Batoh Kota Banda Aceh yang didapat melalui lingkungan sebagai sumber pembelajaran geografi.

Fenomena-fenomena tersebut mempengaruhi proses pembelajaran geografi dengan menggunakan media dan sumber pembelajaran yang berfungsi sebagai alat perangsang stimulan bagi peserta didik agar terjadinya proses pembelajaran yang aktif dan efektif. Media dan sumber pembelajaran berperan sangat penting dalam suatu kegiatan belajar mengajar. Guru dapat menggunakan gambar, foto maupun ilustrasi dan juga mengajak peserta didik untuk melakukan observasi langsung dilapangan dengan menggunakan metode insiden dalam memberikan informasi pada peserta didik, sehingga informasi yang diperoleh peserta didik lebih konkret dan tidak bersifat abstrak, sebagaimana Komalasari (2013:108), mengemukakan bahwa: "Pada hakikatnya, alam semesta ini merupakan sumber belajar bagi manusia sepanjang masa." maka tidak mungkin pengalaman tersebut didapat langsung oleh peserta didik tanpa ada bantuan daripada media dan metode serta sumber belajar, hal ini dapat dilihat pada salah satu wilayah Kota Banda Aceh yaitu pada simpang AMD Batoh yang terletak dalam wilayah Desa Batoh/ Lamdom - Kecamatan Lueng Bata - Kota Banda Aceh yang dulunya pada tahun 2004 masih merupakan lahan kosong (sawah).

Batas kajian penelitian simpang AMD Batoh yang merupakan salah satu wilayah Kota Banda Aceh dan Kecamatan Lueng Bata, untuk peta Administrasi Kota Banda Aceh dan 
Kecamatan Lueng Bata dapat dilihat pada lampiran XIII dan IV, simpang AMD Batoh berada pada desa Batoh lebih detailnya dapat dilihat pada gambar 1.1.

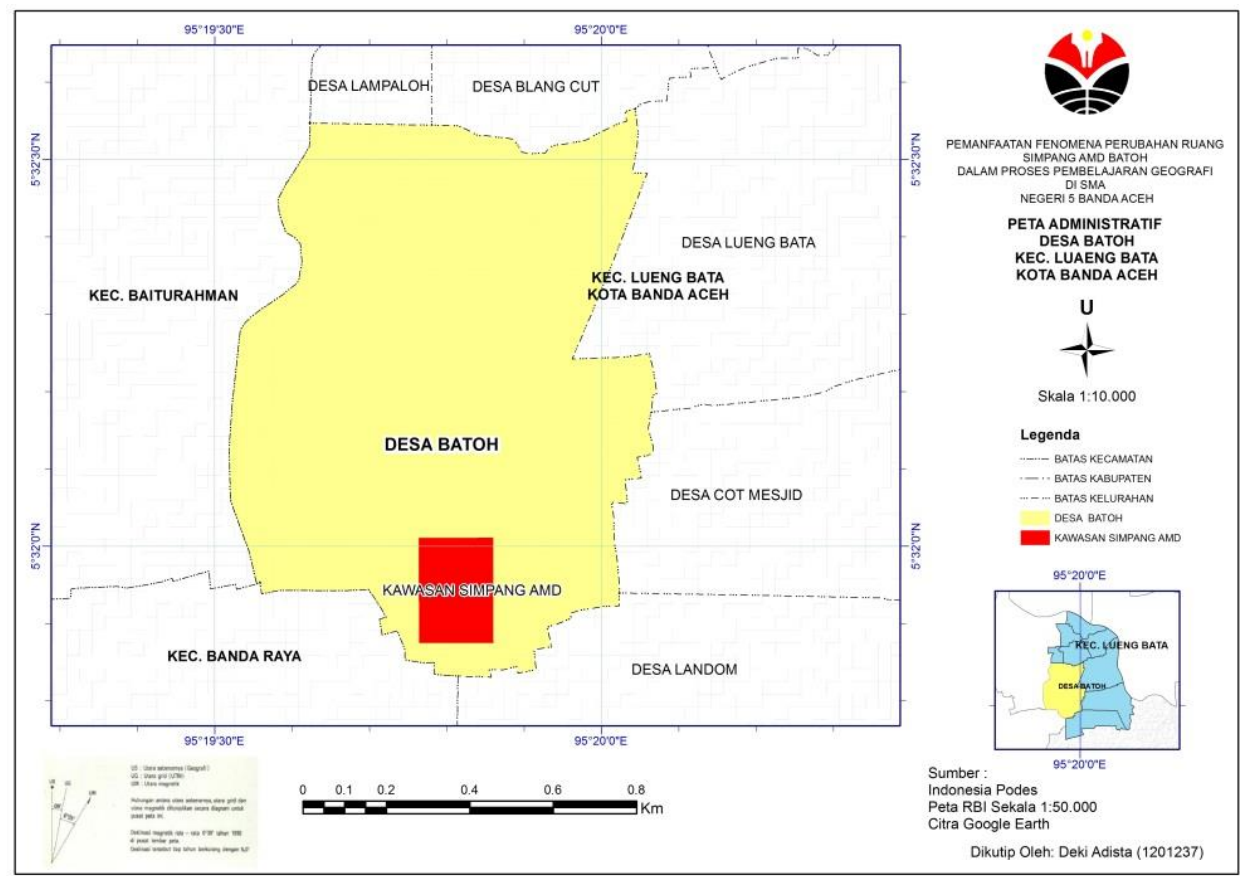

Sumber: Diolah dari Peta RBI Kota Banda Aceh Skala 1: 50.000

Gambar 1.1 : Peta Administrasi desa Batoh.

Luas lahan kosong sebelum terjadi perubahan ruang pada simpang AMD Batoh pada tahun 2004 dapat dilihat pada gambar 1.2.

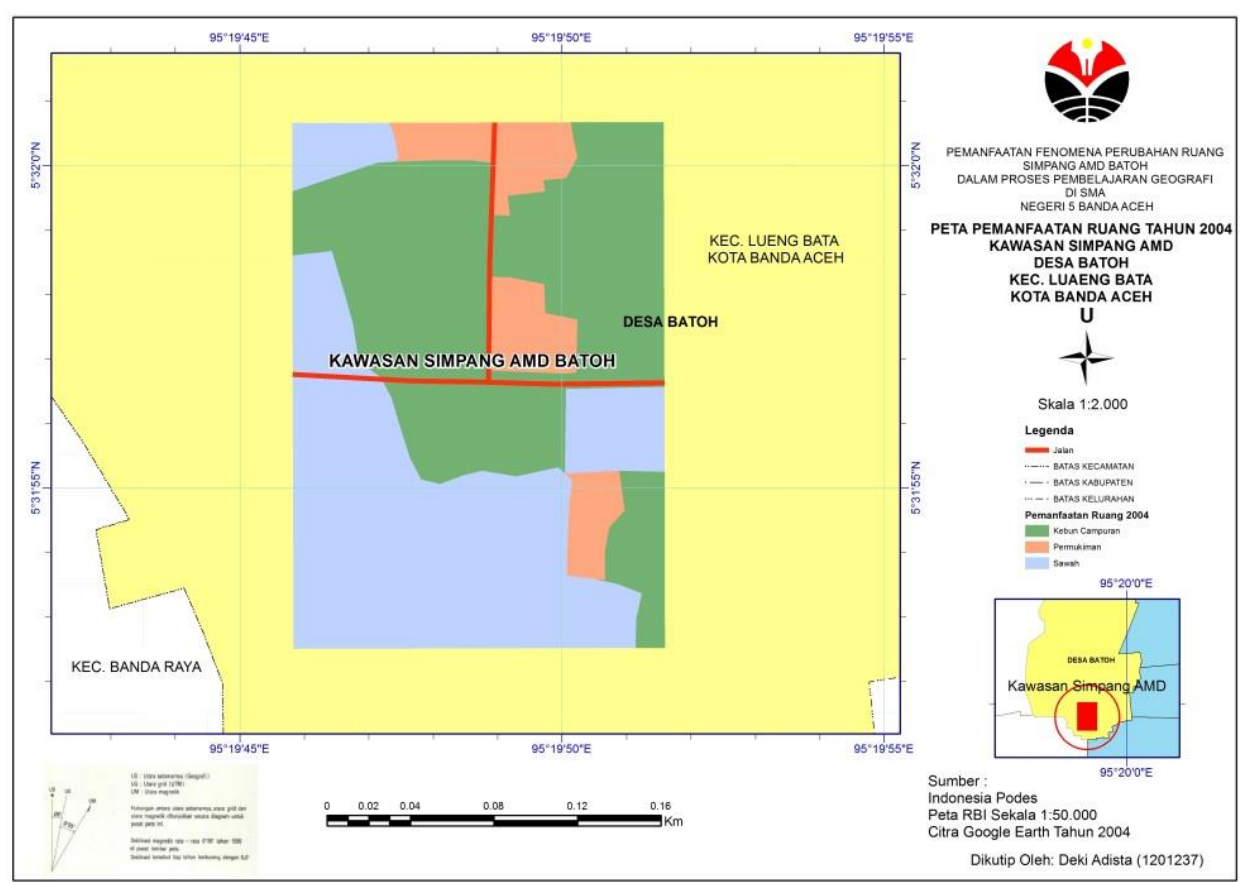


Sumber: Diolah dari Peta RBI Kota Banda Aceh Skala 1: 50.000

Gambar 1.2 : Peta Lahan Kosong Simpang AMD Batoh Sebelum terjadi Perubahan tahun 2004

Pemanfaatan Perubahan ruang pada simpang AMD Batoh dapat dilihat pada gambar 1.3

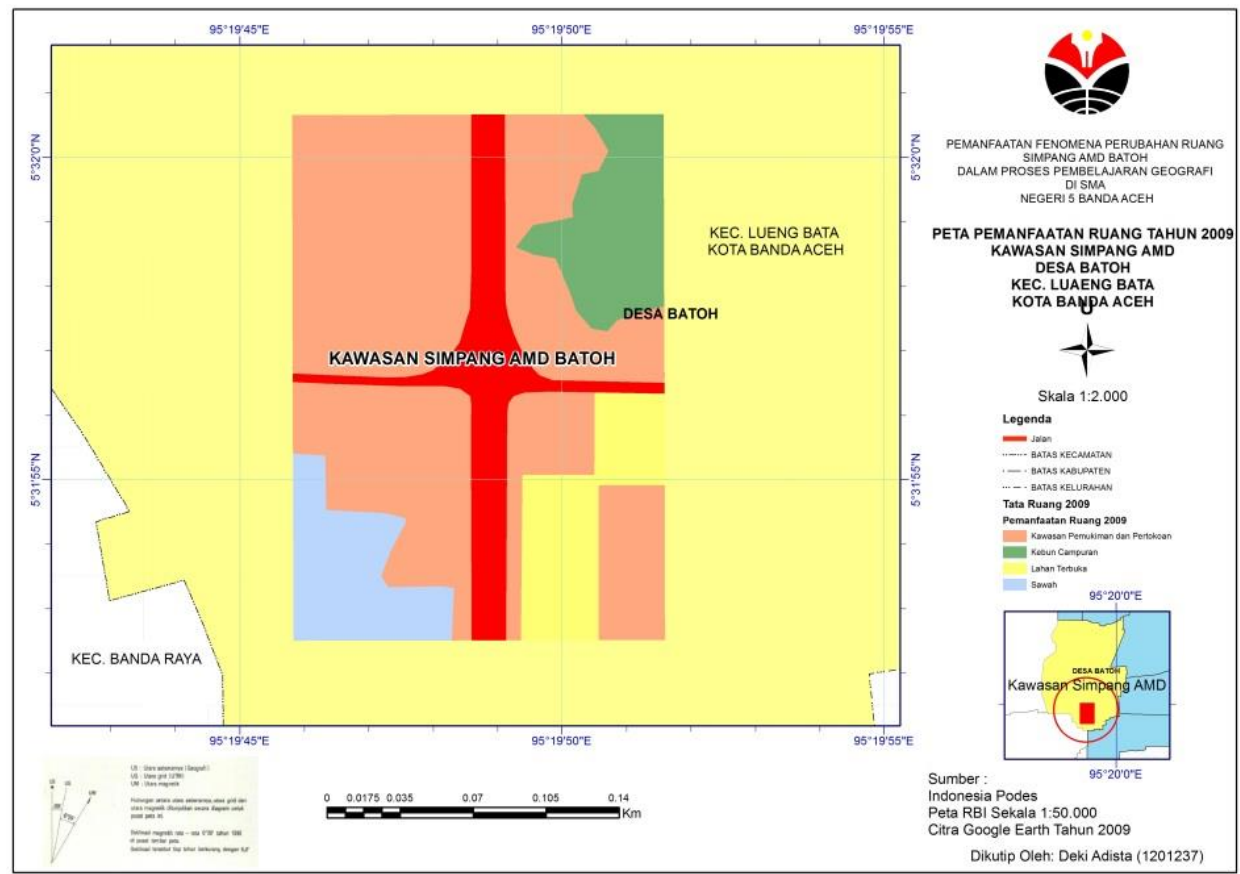

Sumber: Diolah dari Peta RBI Kota Banda Aceh Skala 1: 50.000

Gambar 1.3 : Peta Pemanfaatan Perubahan Ruang Simpang AMD Batoh tahun 2009.

Perubahan pemanfaatan ruang Simpang AMD Batoh tahun 2004 - 2009 dapat dilihat pada gambar 1.4 .

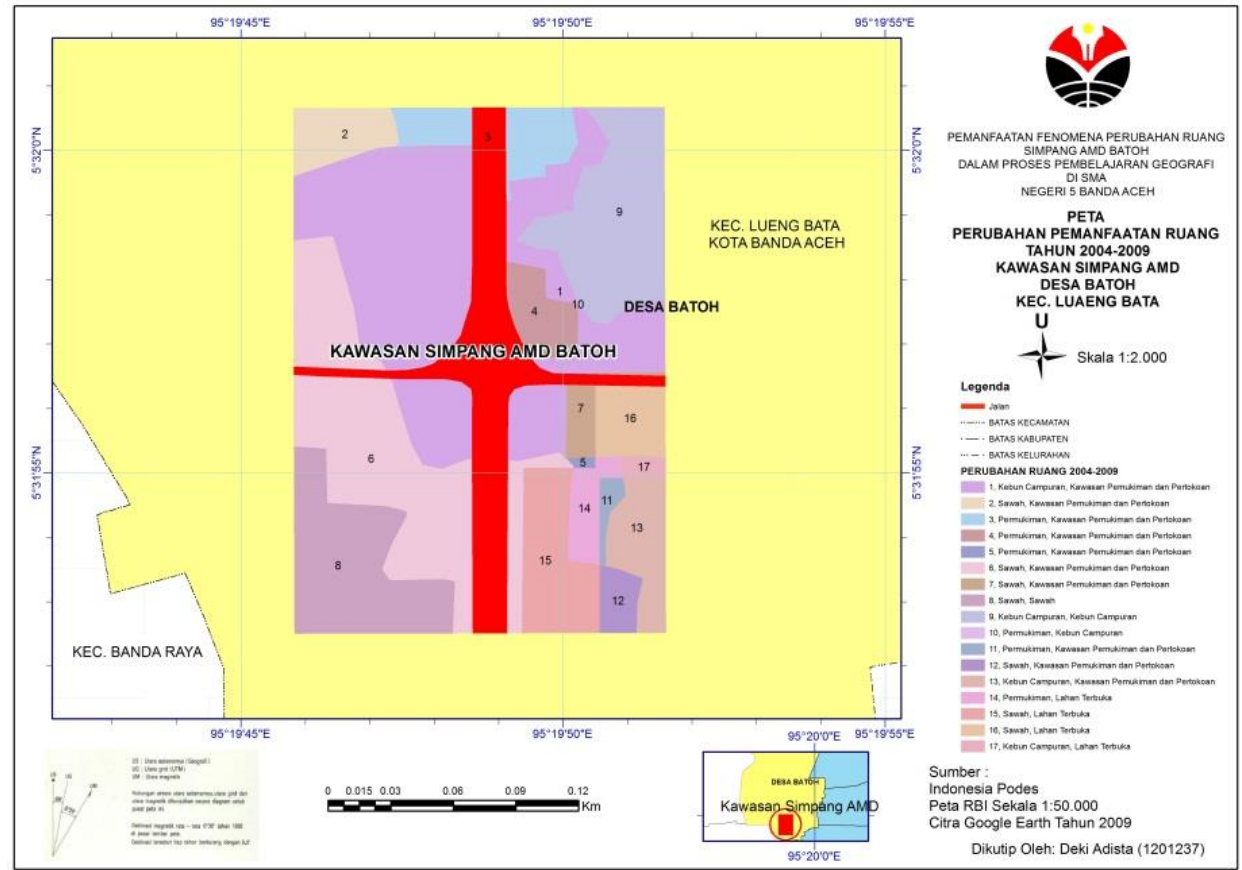


Gambar 1.4 : Peta Perubahan Pemanfaatan Ruang Simpang AMD Batoh tahun 2004 - 2009.

Detailnya dapat dilihat pada tabel Rencana Tata Ruang Wilayah Kota Banda Aceh, yang mana simpang AMD Batoh terletak dalam wilayah Desa Batoh - Kecamatan Lueng Bata Kota Banda Aceh, dan dapat dilihat pada tabel 1.1.

Pihak Kota Banda Aceh dalam mengembangkan pemanfaatan perubahan ruang seharusnya mengajak masyarakat untuk berpartisipasi dalam perencanaan dan pelaksanaan sehingga tidak mempertimbangkan dari beberapa aspek kajian yang harus di kaji dan di analisis secara keruangan dan lingkungan agar tidak menimbulkan kesenjangan-kesenjangan dalam masyarakat khususnya antara manusia dengan manusia, manusia dengan tumbuhan dan manusia dengan binatang sehingga lingkungan sekitar Simpang AMD Batoh tetap terjaga sumber daya alam secara bijak dan arif.

Pelaksanaan perubahan ruang lebih mengedepankan pendekatan kompleks wilayah, dimana pendekatan ini bersifat untuk mengutamakan pelestarian lingkungan dan organisasi keruangan untuk menjamin kebutuhan hidup dan memberikan kemudahan-kemudahan dalam memperoleh serta melindungi dari ancaman-ancaman dan bahaya-bahaya baik yang sifatnya dari proses alam maupun dari proses manusia sebagai pendukung kehidupan makhluk hidup di ruang permukaan bumi dan tidak mengedepankan perkembangan perekonomian tetapi dengan membentuk sebuah perkotaan yang ramah terhadap lingkungan serta meminimalisir dampak daripada lingkungan alam, lingkungan sosial, lingkungan ekonomi dan lingkungan budaya dan tidak mengenyampingkan perkembangan ilmu dan teknologi dalam pelaksanaan perubahan ruang terhadap tempat tinggal kehidupan makhluk hidup yang saling mempengaruhi dan bergantung satu sama lain dalam ruang permukaan bumi.

Berdasarkan latar belakang masalah di atas, maka yang menjadi judul penelitian ini adalah "PEMANFAATAN FENOMENA PERUBAHAN RUANG SIMPANG AMD BATOH DALAM PROSES PEMBELAJARAN GEOGRAFI DI SMA NEGERI 5 BANDA ACEH.” (Kasus Penggunaan Metode Insiden dan Media Gambar/ Foto dan Ilustrasi pada kelas XI).

\section{LANDASAN TEORI}

Perkembangan studi kajian ilmu geografi harus diketahui secara bersama agar para pengembang ilmu pendidikan geografi baik di kalangan masyarakat maupun lembaga pendidikan tidak salah mengartikan sebenarnya yang menjadi kajian disiplin ilmu geografi dalam melakukan penelitian, sebagaimana Bintarto (Arjana, 2013: 21) mengemukakan bahwa: 
Geografi mempelajari hubungan timbal-balik gejala-gejala muka bumi, baik yang fisik maupun yang menyangkut hidup beserta permasalahannya melalui pendekatan keruangan, ekologi, dan regional untuk kepentingan program, proses dan keberhasilan pembangunan.

Pengimplementasian pembangunan berkelanjutan harus dapat memadukan antara dua jenis sumber daya, sumber daya alam dan sumber daya manusia, agar nantinya tidak menimbulkan dampak terhadap lingkungan yang di dalamnya terdapat ruang yang terdiri dari lingkungan alam, lingkungan sosial, lingkungan budaya untuk setiap makhluk dalam mewujudkan tujuan pembangunan yang berkawasan lindung dan kawasan budidaya dan tidak dapat dipisahkan dari perubahan ruang permukaan bumi, baik melalui proses alam maupun melalui proses manusia, sebagaimana Pasya (2002: 51), bahwa:

Segala sesuatu yang terjadi di permukaan bumi satu sama lain (interrelasi) mempunyai hubungan, baik antara benda mati dengan benda mati, makhluk hidup dengan benda mati, atau benda mati dengan makhluk hidup. Kemudian akan timbul saling ketergantungan (interdependensi), akhirnya segala gejala tersebut tidak dapat dilepaskan dari proses evolusi.

Pengkajian, analisis dan penelaahan terhadap studi geografi, baik berupa gejala-gejala dan fenomena-fenomena yang terjadi di dalam ruang permukaan bumi yang berkaitan dengan gejala yang menyangkut dengan suatu lokasi dalam ruang, baik secara fisik, sosial, ekonomi, budaya, politik, serta lingkungan yang berhubungan langsung dengan makhluk hidup dan benda mati serta menyangkut penentuan suatu lokasi dalam permukaan bumi tidak terlepas dari konsep interaksi dan interdepedensi dan kesemuanya merupakan satu kesatuan yang tidak dapat dipisahkan satu sama lain, dapat dilakukan dengan mempelajari geografi sebagai suatu sintesis, geografi sebagai suatu penelaahan gejala dan interelasi keruangan dan geografi sebagai disiplin tata guna lahan. Sumarmi (2012: 36), mengemukakan bahwa:

Perencanaan kota dapat dianggap sebagai bagian dari proses urbanisasi yang dikaitkan dengan penjelasan tujuan perencanaa perkotaan dan dengan penentuan cara-cara untuk mencapai tujuan tersebut. Tujuan-tujuan tersebut (atau harus) dijelaskan kepada masyarakat berdasarkan kebutuhan, keinginan, dan aspirasinya. Laporan perencanaan kota itu penting khususnya pada saat memformulasikan tujuan-tujuan, dan kemudian pada saat pelaksanaan tujuan serta pengujian akibat yang akan terjadi. Tanggung jawab utama perencanaan kota adalah untuk menunjukkan bagaimana caranya mempengaruhi proses pembangunan agar yakin bahwa hasil transformasi struktural dan fungsional permukiman mengarah pada pemenuhan tujuan. Selanjutnya perencanaan dapat juga dilihat sebagai organisasi kegiatan-kegiatan masa mendatang berkenaan dengan pertanyaan di mana? dan kapan? demikianlah, perencanaan secara jelas merupakan alat penting untuk pembangunan secara sadar tentang lingkungan manusia.

Dari pernyataan di atas, pemanfaatan perubahan ruang tidak terlepas dari pengaruh urbanisasi yang dilakukan oleh masyarakat desa ke kota untuk mendapatkan kehidupan yang 
lebih layak, oleh karena itu dalam pelaksanaan pemanfaatan perubahan ruang untuk menampung penduduk yang melakukan urbanisasi, harus memperhatikan tujuan perencanaan kota berdasarkan keinginan, kebutuhan dan aspirasi dari masyarakat, agar tidak terjadi penumpukan penduduk pada satu daerah dan mengurangi mutu kualitas lingkungan yang menjadi pendukung kehidupan masyarakat di perkotaan serta rusaknya lingkungan yang diakibatkan oleh salah satunya tekanan penduduk, serta mengurangi dampak daripada pemanfaatan perubahan ruang yang direncanakan oleh pemerintah dan masyarakat, sebagaimana dikemukakan oleh Worosuprodjo (2007: 15) bahwa:

Tata Ruang menurut Geografi: (1) Tata ruang merupakan wujud struktual ruang dan pola ruang; (2) Sumberdaya ruang meliputi keterpaduan sumberdaya wilayah, lingkungan, sumberdaya alam, manusia dan budayanya; (3) Keseimbangan ruang dan mahkluk hidup merupakan pendekatan yang berbasis ekologis dan keruangan; (4) Satuan wilayah geografis punya makna pewilayahan ekologis dan administratif yang terintegrasi.

Dari pernyataan di atas, di dalam pelaksanaan tata ruang menurut kajian ilmu geografi, setidaknya harus mempertimbangkan dari wujud ruang dan pola ruang dan berbasis pendekatan kompleks wilayah yang mempunyai makna wilayah ekologis dalam satu sistem ruang yang melingkupi daripada segala aspek, baik aspek sosial, budaya, ekonomi, politik, dan lingkungan alam, agar nantinya tidak terjadi hal-hal yang tidak diinginkan oleh perubahan ruang yang tidak memperhitungkan kesejahteraan dan perlindungan kehidupan terhadap makhluk hidup dalam ruang permukaan bumi, sedangkan aspek lingkungan itu sendiri adalah dalam melakukan perencanaan dan perubahan ruang agar tetap menjaga kelestarian dan keseimbangan pada lingkungan, sehingga segala kebutuhan dasar, baik berupa kebutuhan untuk menajalani hidup maupun kebutuhan jasmani dan rohani yang dibutuhkan oleh makhluk hidup dalam ruang permukaan bumi dapat terpenuhi.

Pemanfatan perubahan ruang dalam mewujudkan pembangunan berkelanjutan tanpa melihat lingkungan hidup sebagai ruang di dalamnya sebagai satu sistem keruangan yang tidak dapat dipisahkan, akan mendapat permasalahan baru atau mengakibatkan dampak-dampak daripada usaha perkembangan kota itu sendiri, sebagaimana dikemukakan oleh, Daldjoeni (1998: 134) bahwa: dampak perkembangan kota akibat perubahan pemanfaatan ruang dapat berupa: “(1) Pencemaran air; (2) Pencemaran udara; (3) Pencemaran tanah.”

Perubahan pemanfaatan ruang yang tidak memperhatikan aspek sosial, ekonomi, lingkungan budaya, politik, dan pelestarian lingkungan dalam perubahannya tidak menjadi pertimbangan dalam pelaksanaanya sebagai tempat tinggal makhluk hidup dan benda mati yang mempunyai rasa saling ketergantungan satu sama lain dan pelestarian lingkungan dalam 
implementasi program kurang diperhatikan serta lebih beorientasi pada aspek teknis dan pembangunan ekonomi, maka yang terjadi adalah kerusakan lingkungan serta kurangnya rasa memiliki dan kepedulian terhadap program-program pemerintahan setelah program-program tersebut terselesaikan oleh warga masyarakat, akibatnya mereka bersikap apatis dan cenderung kurang memperhatikan dalam perawatan terhadap berbagai fasilitas yang telah terbangun oleh program-program pemerintahanakan berdampak terhadap ruang baik secara perkembangan ekonomi maupun secara perkembangan kehidupan lingkungan sosial, ekonomi, lingkungan budaya, politik, dan pelestarian lingkungan dalam ruang permukaan bumi, sebagaimana dikemukakan oleh Hammar (2007:17), bahwa: "Dalam pelaksanaan rencana tata ruang kota, diperlukan transparansi, kejujuran dalam implementasinya, manakala hal ini kurang diperhatikan, dikuatirkan menimbulkan persepsi yang kurang baik dari masyarakat.”

Dari pernyataan di atas, pemanfaatan ruang sebelum pelaksanaannya, sangat diperlukan dikarenakan segala sesuatu yang berkaitan dengan ruang baik pada lapisan darat, air dan udara, keseluruhannya agar berdampak langsung terhadap masyarakat, maka dari itu mulai perencanaan sampai dengan tahap implementasi di lapangan sangat diperlukan partisipasi masyarakat dalam pemanfaatan dan penataan ruang dalam mencapai tujuan penataan ruang dengan mengutamakan kejujuran dan transparansi dalam implementasinya, sebagaimana dikemukakan oleh Hammar (2007: 42), bahwa:

Partisipasi masyarakat merupakan hal yang sangat penting dalam penataan ruang karena pada akhirnya hasil-hasil penataan ruang bermuara pada kepentingan masyarakat. Masyarakat berperan sebagai mitra pemerintah dalam penataan ruang dengan mendayagunakan kemampuannya secara aktif sebagai wujud partisipasi masyarakat dalam mencapai tujuan penataan ruang.

Penataan ruang yang mengedepankan partisipasi masyarakat dalam pemanfaatannya untuk dilakukan perubahan, akan menumbuhkembangkan masyarakat berperan aktif dalam pembangunan, karena sesungguhnya yang dilakukan oleh pihak pemerintah dalam ruang permukaan bumi akan berdampak pada lingkungan sosial, ekonomi, lingkungan budaya, politik dan lingkungan alam dimana masyarakat bertempat tinggal, maka sepatutnyalah pemerintah melibatkan masyarakat dalam hal pemanfaatan perubahan ruang mulai dari proses perencanaan sampai dengan proyek pelaksanaan pemanfaatan perubahan ruang, sebagaimana dikemukakan oleh Masengi, (Hammar: 2007: 42), bahwa:

Dalam rangka menumbuhkembangkan kegiatan agar masyarakat berperan serta dalam pembangunan secara aktif, maka para petugas lapangan harus dapat menggali dan menangkap aspirasi yang tumbuh dalam aspirasi masyarakat serta dapat memanfaatkannya sebagai bahan pertimbangan dalam perencanaan atau pelaksanaan. 
Berdasarkan pernyataan di atas, pengumpulan informasi yang sifatnya data fisik dan data sosial dari kebutuhan-kebutuhan dalam perencanaan pemanfaatan ruang dapat diperoleh dari hasil survei lapangan terkait pemanfaatan perubahan ruang dan disesuaikan dengan kebutuhan, keinginan dan aspirasi masyarakat dalam pelaksanaannya, selain dari data survey lapangan dapat mengundang perwakilan-perwakilan daripada tokoh-tokoh masyarakat dalam pelaksanaan pemanfaatan perubahan ruang dalam hal perencanaan sampai proses pelaksanaan pemafaatan perubahan ruang sehingga menjadi bahan kajian dan pertimbangan dalam perencanaan serta pelaksanaannya dalam pemanfaatan perubahan ruang dalam permukaan bumi, sebagaimana Masengi, (Hammar: 2007: 42), bahwa:

Dalam rangka menumbuhkembangkan kegiatan agar masyarakat berperan serta dalam pembangunan secara aktif, maka para petugas lapangan harus dapat menggali dan menangkap aspirasi yang tumbuh dalam aspirasi masyarakat serta dapat memanfaatkannya sebagai bahan pertimbangan dalam perencanaan atau pelaksanaannya.

Dari pernyataan di atas, pencapaian tujuan bersama dalam rangka pemanfaatan ruang keterlibatan masyarakat melalui promosi dan sosialisasi serta mengajak masyarakat untuk menentukan pemanfaatan ruang yang dibutuhkan dan dinginkan oleh masyarakat harus disampaikan melalui aspirasi-aspirasi, baik melalui angket maupun melalui musyawarah yang diadakan oleh pihak pemerintah melalui petugas lapangan sangat diperlukan sebagai data lingkungan sosial, lingkungan ekonomi, lingkungan budaya, lingkungan politik dan pelestarian lingkungan alam, yang didapatkan oleh petugas lapangan terhadap kebutuhan dan keinginan masyarakat dapat menjadi bahan pertimbangan untuk memanfaatkan ruang yang akan dirubah pemanfaatan ruang sebagai suatu kesatuan dalam ruang permukaan bumi.

\section{METODE PENELITIAN.}

Penelitian ini menggunakan pendekatan kuantitatif, dengan metode Eksperiment (Non Ekuivalen (Pre-Test and Post Test) Control Design Grup), sebagaimana Cresswell (2010: 238), mengemukakan bahwa: "Dalam rancangan ini, peneliti menggunakan kelompok control dan kelompok eksperimen, namun tidak secara acak memasukkan (nonrandom-assigment) para partisipan ke dalam dua kelompok tersebut."

PEMBAHASAN HASIL PENELITIAN. 
1. Hasil Tes Pemahaman Konsep pada kelas yang menggunakan metode insiden.

a. Berdasarkan perhitungan tabel dan gambar grafik di atas mengenai nilai pre-test kelas metode insiden terkait fenomena perubahan ruang simpang AMD Batoh dapat diambil kesimpulan bahwa cenderung memiliki kemampuan yang sama dengan perolehan nilai rata-rata pre-test sebesar 31.23.

b. Berdasarkan perhitungan tabel dan gambar grafik di atas mengenai nilai pre-test kelas yang menggunakan metode insiden terkait fenomena perubahan ruang simpang AMD Batoh dapat diambil kesimpulan bahwa pada kelas yang menggunakan metode insiden cenderung memiliki kemampuan yang sama dengan perolehan nilai rata-rata pos-test sebesar 43.08.

c. Berdasarkan perhitungan tabel dan gambar grafik di atas mengenai perbedaan nilai pre-test dan post-test kelas eksperimen yang menggunakan metode insiden terkait fenomena perubahan ruang simpang AMD Batoh dapat diambil kesimpulan bahwa terdapat perubahan nilai yang signifikan antara hasil nilai pre-test terhadap nilai post-test dengan perolehan skor korelasi sebesar 0.87, ini menunjukkan bahwa proses pembelajaran geografi dengan menggunakan metode insiden cenderung lebih jelas dan lebih luas jangkauannya dalam memperlihatkan situasi dan kondisi yang kontekstual yang bersifat lokal karena langsung terjun ke lapangan untuk melakukan observasi langsung terkait pemanfaatan fenomena perubahan ruang simpang AMD Batoh.

d. Berdasarkan tabel dan gambar di atas mengenai perbedaan gain dan kenaikan rata-rata pada kelas yang menggunakan metode insiden, maka dapat diambil kesimpulan bahwa untuk pencapaian gain semakin besar usaha seseorang untuk mencapai kenaikan pada pencapaian skor maximal, maka semakin kecil pula skor yang di dapat dengan menggunakan metode insiden dengan nilai rata-rata gain pretest dan post-test adalah 0.17 , sedangkan pencapaian kenaikan untuk skor maksimal semakin besar nilai seseorang untuk peningkatan, maka semakin kecil pula usaha yang dikeluarkan dengan menggunakan metode Insiden dengan nilai rata-rata pretest dan post-test adalah 74.31, ini menunjukkan bahwa lebih besar usaha peserta didik maka nilai yang didapat lebih kecil untuk mencapai skor maksimal dalam proses pembelajaran geografi dengan menggunakan metode insiden yang hanya memperlihatkan pada satu titik lokasi saja dan tidak memperlihatkan secara keseluruhan di daerah lokasi yang terjadi perubahan secara konstektual dan lokal terkait fenomena perubahan ruang Simpang AMD Batoh.

2. Hasil Tes Pemahaman Konsep dengan meggunakan Media Gambar. 
a. Nilai pre-test kelas yang menggunakan media gambar/ foto dan ilustrasi terkait fenomena perubahan ruang simpang AMD Batoh dapat diambil kesimpulan bahwa pada kelas media gambar/ foto dan ilustrasi cenderung memiliki kemampuan yang sama dengan perolehan nilai rata-rata pre-test sebesar 36.

b. nilai post-test kelas yang menggunakan media gambar/ foto dan ilustrasi terkait fenomena perubahan ruang simpang AMD Batoh dapat diambil kesimpulan bahwa pada kelas yang menggunakan Media Gambar/ Foto dan Ilustrasi cenderung memiliki kemampuan yang sama dengan perolehan nilai rata-rata pre-test sebesar 47.48 .

c. Perbedaan nilai pre-test dan post-test kelas media gambar/ foto dan ilustrasi yang menggunakan metode insiden terkait fenomena perubahan ruang simpang AMD Batoh dapat diambil kesimpulan bahwa terdapat perubahan nilai yang signifikan antara hasil nilai pre-test terhadap nilai post-test dengan perolehan skor korelasi sebesar 0.70, ini menunjukkan bahwa proses pembelajaran geografi dengan media gambar/ foto dan ilustrasi cenderung lebih jelas dan lebih luas jangkauannya dalam memperlihatkan situasi dan kondisi yang kontekstual yang bersifat lokal karena langsung terjun ke lapangan untuk melakukan observasi langsung terkait pemanfaatan fenomena perubahan ruang simpang AMD Batoh.

d. Perbedaan gain dan kenaikan rata-rata pada kelas yang menggunakan metode insiden, maka dapat diambil kesimpulan bahwa untuk pencapaian gain semakin besar usaha seseorang untuk mencapai kenaikan pada pencapaian skor maximal, maka semakin kecil pula skor yang di dapat dengan menggunakan metode insiden dengan nilai rata-rata gain pretest dan post-test adalah 0.18 , sedangkan pencapaian kenaikan untuk skor maksimal semakin besar nilai seseorang untuk peningkatan, maka semakin kecil pula usaha yang dikeluarkan dengan menggunakan metode Insiden dengan nilai rata-rata pretest dan post-test adalah 100, ini menunjukkan bahwa lebih besar usaha peserta didik maka nilai yang didapat lebih kecil untuk mencapai skor maksimal dalam proses pembelajaran geografi dengan menggunakan metode insiden yang hanya memperlihatkan pada satu titik lokasi saja dan tidak memperlihatkan secara keseluruhan di daerah lokasi yang terjadi perubahan secara konstektual dan lokal terkait fenomena perubahan ruang Simpang AMD Batoh.

3. Proses pembelajaran geografi penggunaan metode gambar foto dan ilustrasi pada kelas kontrol diperoleh sebesar $82 \%$, sedangkan pada kelas eksperimen yang menggunakan metode insiden diperoleh sebesar $81.6 \%$, ternyata antara media gambar/ foto dan ilustrasi dengan penggunaan metode insiden terkait fenomena pemanfaatan perubahan ruang simpang AMD Batoh tidak ada yang lebih unggul dengan kata lain dalam proses 
pembelajaran geografi terkait pemahaman konsep fenomena perubahan ruang dapat menggunakan media gambar/ foto dan ilustrasi atau metode insiden, tidak selamanya teori yang dibangun dalam landasan teoritis sejalan dengan hasil penelitian yang didapatkan dilapangan.

\section{SIMPULAN DAN SARAN}

\section{Kesimpulan}

Berdasarkan hasil penelitian dan pengolahan data yang telah dilakukan di SMA Negeri 5 Banda Aceh, maka dapat diambil kesimpulan sebagai berikut:

a. Hasil Tes Pemahaman Konsep pada kelas yang menggunakan metode insiden.

1) Nilai pre-test kelas metode insiden, cenderung memiliki kemampuan yang sama terkait fenomena perubahan ruang simpang AMD Batoh.

2) Nilai post-test kelas yang menggunakan metode insiden, cenderung memiliki kemampuan yang sama terkait fenomena perubahan ruang simpang AMD Batoh.

3) Proses pembelajaran geografi dengan menggunakan metode insiden cenderung lebih jelas dan lebih luas jangkauannya dalam memperlihatkan situasi dan kondisi yang kontekstual yang bersifat lokal karena langsung terjun ke lapangan untuk melakukan observasi langsung terkait pemanfaatan fenomena perubahan ruang simpang AMD Batoh.

4) Perbedaan gain dan kenaikan rata-rata pada kelas metode insiden, lebih besar usaha peserta didik maka nilai yang didapat lebih kecil untuk mencapai skor maksimal dalam proses pembelajaran geografi dengan menggunakan metode insiden yang hanya memperlihatkan pada satu titik lokasi saja dan tidak memperlihatkan secara keseluruhan di daerah lokasi yang terjadi perubahan secara konstektual dan lokal terkait fenomena perubahan ruang Simpang AMD Batoh.

b. Hasil Tes Pemahaman Konsep dengan meggunakan Media Gambar/ Foto dan Ilustrasi.

1) Nilai pre-test kelas yang menggunakan media gambar/ foto dan ilustrasi terkait fenomena perubahan ruang cenderung memiliki kemampuan yang sama terkait fenomena perubahan ruang simpang AMD Batoh.

2) Nilai post-test kelas yang menggunakan media gambar/ foto dan ilustrasi terkait fenomena perubahan ruang, cenderung memiliki kemampuan yang sama terkait fenomena perubahan ruang simpang AMD Batoh.

3) Proses pembelajaran geografi media gambar/ foto dan ilustrasi cenderung lebih jelas dan lebih luas jangkauannya dalam memperlihatkan situasi dan kondisi yang kontekstual yang bersifat lokal terkait pemanfaatan fenomena perubahan ruang simpang AMD Batoh. 
4) Perbedaan gain dan kenaikan rata-rata pada kelas media gambar/ foto dan ilustrasi, lebih besar usaha peserta didik maka nilai yang didapat lebih kecil untuk mencapai skor maksimal dalam proses pembelajaran geografi dengan menggunakan media gambar/ foto dan ilustrasi yang hanya memperlihatkan pada satu titik lokasi saja dan tidak memperlihatkan secara keseluruhan di daerah lokasi yang terjadi perubahan secara konstektual dan lokal terkait fenomena perubahan ruang Simpang AMD Batoh.

c. Tidak terdapat perbedaan yang signifikan antara media gambar/ foto dan ilustrasi dengan penggunaan metode insiden dalam proses pembelajaran geografi terkait pemahaman konsep terkait fenomena pemanfaatan perubahan ruang simpang AMD Batoh.

\section{Saran}

a. Diharapkan Bagi Dinas Pendidikan, hasil penelitian ini dapat dijadikan sebagai bahan kajian lebih lanjut untuk mengambil kebijakan pendidikan yang berhubungan dengan penggunaan lingkungan sebagai sumber belajar yang bersifat kontekstual dan konten lokal dalam proses pembelajaran geografi.

b. Diharapkan Bagi kepala sekolah, untuk meningkatkan kinerja guru dalam proses pembelajaran geografi.

c. Diharapkan Bagi guru sebagai bahan kajian, untuk meningkatkan kinerja dan produktifitas kerja dalam proses pembelajaran geografi sesuai dengan materi pokok bahasan agar tercapainya tujuan pembelajaran sebagaimana yang diharapkan dengan menggunakan lingkungan sebagai sumber belajar.Diharapkan dalam penelitian selanjutnya untuk peningkatan pemahaman konsep perubahan ruang mendapatkan kemudahan dalam pelaksanaannya terkait dengan faktor kendala dan prosedur pelaksanaan di lapangan.

d. Diharapkan dalam penelitian selanjutnya mendapatkan kemudahan dari sę̧ ’ ' endala dan prosedur pelaksanaan terkait peningkatan pemahaman konsep perubahan ruang.

\section{DAFTAR PUSTAKA}

Alfan. (2013). Filsafat Kebudayaan. Bandung: Pustaka Setia.

Arjana, B, J. (2013), Geografi Lingkungan Sebuah Introduksi. Jakarta: RajaGrafindo Persada.

Bakosurtanal. (1997). Peta Rupa Bumi Indonesia Banda Aceh, lembar 0421-52, Skala 1: 50.000, Penerbit: Bogor: Bakosurtanal

Bintarto \& Hadisumarno, S. (1991). Metode Analisa Geografi, Jakarta: Lembaga Penelitian, Pendidikan dan Penerangan Ekonomi dan Sosial (LP3ES). 
Cresswell. J. W. (2010). Research Design, Pendekatan Kualitatif, Kuantitatif, dan Mixed. Yogyakarta: Pustaka Pelajar.

Daldjoeni, N. (1998). Geografi Desa dan Kota (Edisi Revisi). Penerbit: PT Alumni.

Jayadinata, J. T. (1999). Tata Guna Tanah Dalam Perencanaan Pedesaan Perkotaan Dan Wilayah. Penerbit: ITB Bandung.

Hammar, R.K.R. (2007). Pelaksanaaan tata ruang di kota manokwari. Mata Kuliah Tata Ruang. Yogyakarta: Sekolah Pascasarjana Universitas Gadjah Mada. Di akses dari www.google.com/ www.mah-eisa.ac.idMakalah-Tata-Ruang.pdf

Najmulmunir, N. (tanpa tahun). Analisis Dampak Penggunaan Ruang Terhadap Risiko Perubahan Iklim: Studi Kasus Provinsi Lampung, Staf Pengajar Magister Ilmu Pemerintahan dan Fakultas Pertanian Universitas Islam "45" Bekasi diakses dari http://www.google.com/url.www.ejournal-unisma.net.

Ningrum. E. (2006). Tempat, Ruang dan sistem sosial. diakses dari http://www.google.com/url?httpfile.upi.edu.Direktori.FFPIPSJUR._PEND._GEOGR AFI.EPON_NINGRUMTEMPATRUANG_DAN_SISTEM_SOSIALTEMPAT_RU ANG_DAN_SISTEM_SOSIAL.pdf.

Nugroho, I. \& Dahuri. R. (2004). Pembangunan Wilayah Perspektif Ekonomi, Sosial dan Lingkungan. Jakarta: Pustaka LP3ES Indonesia.

Pasya, G. K. (2002). Geografi Pemahaman Konsep dan Metodologi. Bandung: Buana Nusantara.

Poerwanto, H. (2010). Kebudayaan dan Lingkungan dalam Perspektif Antropologi. Yogyakarta: Pustaka Pelajar.

Soetomo, S. (2009). Urbanisasi \& Morfologi Proses Perkembangan Peradaban \& Wadah Ruang Fisiknya: Menuju Ruang Kehidupan yang Manusiawi. Yogyakarta: Graha Ilmu.

Sujatmoko. (1992). Pembangunan Berkelanjutan. Mencari Format Politik. Jakarta: PT Gramedia Pustaka Utama Bekerja sama dengan Yayasan SPES.

Sumaatmaja, N. (1981). Studi Geografi Suatu Pendekatan dan Analisa Keruangan. Bandung: Alumni.

Sumarmi. (2012). Pengembangan Wilayah Berkelanjutan. Yogyakarta: Aditya Media Publishing.

Supardan, D. (2009). Pengantar Ilmu Sosial Sebuah Kajian Pendekatan Struktural. Jakarta: Bumi Aksara.

Walikota Banda Aceh, Penjelasan Rancangan Qanun Kota Banda Aceh Nomor 4 Tahun 2009 Tentang Rencana Tata Ruang Wilayah Kota Banda Aceh, 2009 - 2029, diakses dari http://www.google.com/urlwebhttpciptakarya.pu.go.idpbldocperdartrwQanun42009 kotabandaaceh.pdf. 
Walikota Banda Aceh, Hasil Rencana Tata Ruang Wilayah Kota Banda Aceh, 2009, diakses dari http://www.google.com/url=httpbappeda.bandaacehkota.go.idwpcontentdownloadrtrwBABIIIRencanaStrukturRuangpdf.

Worosuprodjo. S. (2007). Tata Ruang Geografis Tata Ruang Geografis Sebagai Dasar Dalam Sebagai Dasar Dalampembangunan Wilayah Berkelanjutan Pembangunan Wilayah Berkelanjutandi Indonesia. Makalah disampaikan pada Seminar dan Kongres IGEGAMA ke 5 di Balairung UGM tanggal 27 Oktober 2007. Staf Pengajar Fakultas Geografi UGM, Yogyakarta diakses dari https://www.google.com/pemanfaatanperubahanruanggeografipemanfaatanperubahan ruanggeografi.

Yunus. H.S. (2010). Metodologi Penelitian Wilayah Kontemporer. Yogyakarta: Pustaka Belajar. 